\title{
Effect of Tea Polyphenols on $\alpha$-Amylase Activity in Starch Hydrolysis
}

(Kesan Polifenol Teh terhadap Aktiviti $\alpha$-Amilase pada Hidrolisis Kanji)

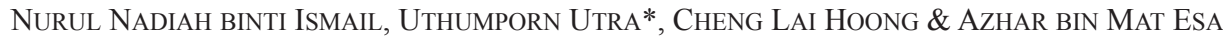

\begin{abstract}
Tea leaves (Camellia sinensis) contain bioactive compounds that can help prevent certain diseases. In this study, the inhibitory effect of polyphenolic components of different types of tea leaves (green, oolong and black) extracted using different solvents (ethanol, methanol and water) on $\alpha$-amylase activity of human saliva were investigated in vitro. Total phenolic content (TPC), total flavonoid content (TFC), ferric reducing/antioxidant power and inhibition of free radical scavenging activity by 1,1-diphenyl-2-picrylhydrazyl of the extracts were measured. Content of gallic acid, caffeine and four catechins also were quantified by high performance liquid chromatography. The ethanol extracts had the highest TPC (124.34-231.23 mg gallic acid equivalents (GAE)/g sample), followed by the methanol extracts (124.28-209.76 mg GAE/g sample) and the water extracts (66.89-136.51 mg GAE/g sample). All three solvent extractions of green tea leaves contained the highest TPC, TFC and antioxidant activity, followed by oolong and black tea leaves. Green tea leaves contained higher amounts of catechins than oolong and black tea leaves. All four catechins were detected in green and oolong tea leaves but only gallocatechin gallate was found in black tea leaves. Next, the effect of tea leaves extracts on starch hydrolysis by a-amylase enzyme from human saliva at $37^{\circ} \mathrm{C}$ was studied. The starches were hydrolyzed with $0.01 \%$ enzyme for 240 min and the extent of hydrolysis was determined based on the dextrose equivalent value. The extent of starch hydrolysis by the tea leaves was as follows: green tea $>$ oolong tea $>$ black tea. The low degree of hydrolysis for black tea was due to its strong inhibitory effect on $\alpha$-amylase activity. Thus, green, oolong and black tea leaves inhibit activity of $\alpha$-amylase to different degrees due to their differing compositions and structures of phenolic compounds.
\end{abstract}

Keywords: $\alpha$-amylase activity; black tea; green tea; hydrolyzing starch; oolong tea; phenolic content

\section{ABSTRAK}

Daun teh (Camellia sinensis) mempunyai sebatian bioaktif sebagai pencegahan penyakit tertentu. Penyelidikan ini mengkaji tentang kesan perencatan enzim $\alpha$-amylase oleh komponen polifenol daripada pelbagai jenis daun teh (hijau, oolong dan hitam) dengan menggunakan kaedah pengekstrakan (etanol, metanol dan air) yang berlainan secara in vitro. Dalam kajian ini, penentuan jumlah kandungan fenolik (TPC), jumlah kandungan flavonoid (TFC), pengurangan kuasa ferum antioksidan (FRAP) dan perencatan aktiviti pembasmian radikal bebas oleh 1,1-difenil-2-picrilhidrazil (DPPH) dijalankan. Kandungan asid gallik, kafein dan empat jenis catechin telah dianalisis dan diukur dengan menggunakan alat analisis kromatografi cecair prestasi tinggi (HPLC). Pengekstrakan etanol menghasilkan jumlah kandungan fenolik tertinggi (124.34-231.23 mg GAE/g sampel), diikuti dengan pengekstrakan metanol (124.28-209.76 mg GAE/g sampel) dan pengekstrakan menggunakan air (66.89-136.51 mg GAE/g sampel). Ketiga-tiga jenis larutan pengekstrakan menunjukkan daun teh hijau mempunyai kandungan TPC, TFC dan antioksidan tertinggi diikuti oleh daun teh oolong dan daun teh hitam. Daun teh hijau mengandungi jumlah katekin lebih tinggi daripada daun teh oolong dan daun teh hitam. Keempat-empat katekin dijumpai terkandung dalam daun teh hijau dan teh oolong, tetapi hanya gallokatecin gallat sahaja dijumpai dalam teh hitam. Selain itu, kesan penambahan ekstrak daun teh pada hidrolisis kanji dengan menggunakan enzim $\alpha$-amilase daripada air liur manusia pada suhu $37^{\circ} \mathrm{C}$ telah dikaji. Kanji telah dihidrolisiskan dengan menggunakan enzim berkepekatan $0.01 \%$ selama 240 min dan kadar hidrolisis ditentukan oleh nilai bersamaan dektrosa. Keputusan hidrolisis kanji ditunjukkan dalam urutan: teh hijau > teh oolong > teh hitam. Tahap hidrolisis terendah untuk teh hitam terbukti daripada perencatan tertinggi teh hitam pada aktiviti enzim $\alpha$-amilase. Ini membuktikan bahawa penambahan daun teh yang berbeza menunjukkan tahap perencatan aktiviti enzim $\alpha$-amilase yang berbeza kerana komposisi dan struktur sebatian fenolik yang berbeza pada setiap jenis daun teh.

Kata kunci: Aktiviti $\alpha$-amilase; teh hitam; teh hijau; hidrolisis kanji; teh oolong; kandungan fenolik

\section{INTRODUCTION}

Phenolic compounds, which are secondary metabolites of a wide range of plants, have properties that are beneficial to health. The results of laboratory and clinical studies suggested that polyphenol-rich plants promote cardiovascular and metabolic health (Chen et al. 2009; 
Tresserra et al. 2014) and have cancer prevention properties (Bhoo et al. 2010). Polyphenols are natural antioxidants from plants that are consumed in the form of fruits, vegetables and beverages such as tea, coffee and wine (Uchenna et al. 2010).

Tea made from Camellia sinensis plant is the most widely consumed beverage in the world following water and is valued for its taste, aroma, antioxidant properties (Khokhar \& Magnusdottir 2002) and essential mineral elements (Szmcycha-Madeja et al. 2015). Tea leaves are categorized into different classes based on the degree of fermentation during processing. During fermentation, flavan-3-ols, the bioactive polyphenols in tea leaves, undergo polyphenol oxidase-dependent oxidative polymerization, resulting in the formation of theaflavins and thearubigins (Lin et al. 2003). Green tea is unfermented and contains the highest concentration of flavan-3-ols. Oolong tea is a partially fermented and contains a mixture of flavan-3-ols, theaflavins and thearubigins. Black tea is fully fermented and contains abundant theaflavins and thearubigins (converted from monomeric catechins or flavan-3-ols), but limited or no flavan-3-ols (JeszkaSkowron et al. 2015).

Tea leaves contain 10-30\% dry weight of polyphenols, including catechins, flavonols, flavanones, phenolic acids, glycosides and the aglycones of plant pigments (Pan et al. 2003). Tea extracts contain powerful antioxidants and major tea catechins, including $(+)$-catechin $(\mathrm{C})$, (-)-epicathecin (EC), (-)-epigallo-catechin (EGC), $(-)$-epicatechin-3-gallate (ECG) and (+)-gallocatechin gallate (GCG) (Naldi et al. 2014; Rusak et al. 2008; Zimmermann \& Gleichenhagen 2011). Gallic acid and caffeine are also present. The composition of phenolic compounds and antioxidants in commercial tea differs with variety, season, leaves maturity, climate and horticultural practices (Kim et al. 2011).

$\alpha$-amylases catalyze hydrolysis of the $\alpha$-1,4-glucosidic linkage of starch and split starch components such as amylose and amylopectin into smaller oligosaccharides, including maltose. Polyphenols are known to inhibit the activity of digestive enzymes such as $\alpha$-amylase and $\alpha$-glucosidase, leading to a decrease in post-prandial hyperglycemia (Bailey et al. 2001). Previous research suggested that polyphenols can retard the absorption of glucose by inhibition of carbohydrate hydrolyzing enzymes and can be important in management of type 2 diabetes mellitus (Apostolidis \& Lee 2010). Kwon et al. (2008) reported that green tea had the lowest $\alpha$-glucosidase inhibitory effect followed by oolong and black tea. These findings suggested that $\alpha$-glucosidase inhibitory activity may depend on catechin polymerization products that are produced during fermentation of the tea leaves.

The goal of this study was to evaluate anti-diabetic potential of different types of extracts (of green, oolong and black tea) by measuring their in vitro inhibitory effects on $\alpha$-amylase. Total phenolic content (TPC), total flavonoid content (TFC) and antioxidant activity of different types of tea leaves were evaluated in extracts obtained using different solvents $(50 \%(\mathrm{v} / \mathrm{v})$ ethanol, $50 \%(\mathrm{v} / \mathrm{v})$ methanol and water).

\section{MATERIALS AND METHODS}

\section{MATERIALS}

In this experiment, tea leaves (Camellia sinensis) was obtained from local market in Penang. Three types of tea leaf were used, i.e. green tea, black tea and oolong tea. $\alpha$-amylase enzyme from human saliva (type XI) was obtained from Sigma-Aldrich Sdn. Bhd. The optimum $\mathrm{pH}$ of $\alpha$-amylase from human saliva (type $\mathrm{XI}$ ) is 6.9 and recommended temperature for this enzyme is $37^{\circ} \mathrm{C}$. Methanol, ethanol, Folin-Ciocalteu's (FC) phenol reagent, sodium nitrite, sodium acetate, aluminium chloride, ferrous sulphate, ferric chloride and sodium carbonate were purchased from R\&M Chemicals (Essex,UK). 2,4,6-Tris (1-pyridyl)-5-triazine (TPTZ) and 1,1-diphenyl2-picrylhydrazyl (DPPH) were purchased from the Fluka company (Switzerland), while gallic acid and catechin were purchased from Sigma-Aldrich (St.Louis,USA).

\section{WATER EXTRACTION}

About $7 \mathrm{~g}$ of different types of tea leaves (green tea, black tea and oolong tea) were infused in $140 \mathrm{~mL}$ water. Then the tea solution was stirred by using magnetic stirrer on a hot plate (magnet $4.5 \times 0.5 \mathrm{~cm}$; hotplate stable temperature, Cole Palmer Instrumental Company, Bunker Court,USA) for $3 \mathrm{~h}$ at $\left(25 \pm 1^{\circ} \mathrm{C}\right)$. After that, the tea extracts were filtered by using muslin cloth and centrifuged (KUBOTA 5100 Centrifuge, Japan) for $30 \mathrm{~min}$ at $700 \mathrm{~g}$. Next, the tea extract were placed in reagent bottle and stored at the temperature of $4^{\circ} \mathrm{C}$ for further analysis. The extracts were wrapped with aluminium foil throughout the extraction process. Each of extraction were done in a triplicate $(n=3)$.

\section{ORGANIC SOLVENT EXTRACTION}

Similar procedures as water extraction were repeated but in this case, methanol and ethanol were used as a solvent of extraction, respectively. The concentration of methanol and ethanol were $50 \%(\mathrm{v} / \mathrm{v})$.

\section{DETERMINATION OF TOTAL PHENOLICS CONTENT}

Total phenol content (TPC) was determined according to the Folin-Ciocalteu's assay method adopted by Chan et al. (2010). Briefly, $300 \mu \mathrm{L}$ of the sample was mixed with $1.5 \mathrm{~mL}$ of Folin-Ciocalteu reagent at $10 \%$ concentration. The mixture was left for $5 \mathrm{~min}$ and then it was added with $1.2 \mathrm{~mL}$ of sodium carbonate $(7.5 \%, \mathrm{w} / \mathrm{v})$. The mixture was left at room temperature $\left(25 \pm 1^{\circ} \mathrm{C}\right)$ and under dark condition for $30 \mathrm{~min}$. The absorbance was measured at $725 \mathrm{~nm}$ using UV-visible spectrophotometer, Shimadzu UV-160A PC (Kyoto, Japan). Each of the samples were done in a triplicate $(n=3)$. The result was presented in form of milligrams of gallic acid equivalent per $g$ of 
sample (GAE mg/g). The standard curve of gallic acid was prepared for concentration of $20,40,60,80$ and $100 \mathrm{mg} / \mathrm{L}$.

\section{DETERMINATION OF FLAVONOIDS CONTENT}

Total flavonoid content (TFC) was determined according to the method reported by Liu et al. (2008). Briefly, 500 $\mu \mathrm{L}$ of sample was added with $2.5 \mathrm{~mL}$ of distilled water. Subsequently, about $150 \mu \mathrm{L}$ of sodium nitrite solution $(5 \%$ $\mathrm{w} / \mathrm{v}$ ) was added to the mixture and kept for $5 \mathrm{~min}$, followed by adding $300 \mu \mathrm{L}$ of aluminium chloride $(10 \% \mathrm{w} / \mathrm{v})$. After that, $1 \mathrm{~mL}$ of $1 \mathrm{M}$ sodium hydroxide $(\mathrm{NaOH})$ was added to the solution. The mixture was further diluted with $550 \mu \mathrm{L}$ of distilled water and shaken vigorously. The absorbance of the mixture was measured at $510 \mathrm{~nm}$ using UV-visible spectrophotometer, Shimadzu UV-160A PC (Kyoto, Japan). Each of the samples were done in a triplicate $(n=3)$. The result was presented in form of milligrams of catechin standard equivalents per $\mathrm{g}$ of sample (CEQ $\mathrm{mg} / \mathrm{g}$ ). The standard curve of catechin was prepared for concentration of $20,40,60,80$ and $100 \mathrm{mg} / \mathrm{L}$.

\section{DETERMINATION OF FERRIC REDUCING ANTIOXIDANT POWER ASSAY}

Assay was performed according to the method described by Benzie and Szeto (1999). FRAP reagent was freshly prepared by mixing $100 \mathrm{~mL}$ of acetate buffer $(0.3 \mathrm{M}$, $\mathrm{pH} 3.6), 10 \mathrm{~mL}$ of 2,4,6-tris(2-pyridyl)-5-triazine (TPTZ) solution (10 mM in $40 \mathrm{mM}$ THCL) and $10 \mathrm{~mL}$ of $\mathrm{FeCl} 3.6 \mathrm{H} 2 \mathrm{O}(20 \mathrm{mM})$ solution. Firstly, $60 \mu \mathrm{L}$ of the samples were added to $3 \mathrm{~mL}$ of FRAP reagent. Then, the mixture was incubated in the water bath at $37^{\circ} \mathrm{C}$ for $4 \mathrm{~min}$. The absorbance of the mixture was measured at $593 \mathrm{~nm}$ using UV-visible spectrophotometer, Shimadzu UV-160A PC, (Kyoto, Japan). Each of the samples were done in a triplicate $(n=3)$. The result was presented in the form of micromoles of ferrous sulphate, FeSO4.7H2O equivalent per $\mathrm{g}$ of sample (Fe (II) $\mu \mathrm{M} / \mathrm{g}$ ). The standard curve of ferrous sulphate was prepared for concentration of 200 , 400, 600, 800 and $1000 \mu \mathrm{M}$.

\section{DETERMINATION OF FREE RADICAL SCAVENGING ABILITY} (DPPH)

The capacity of the tea extract to scavenge the 1,1-diphenyl2-picrylhydrazyl (DPPH) radical activity assay was performed according to Sanchez-Moreno et al. (1998). DPPH reagent was prepared by dissolving $5.9 \mathrm{mg}$ of DPPH powder in $100 \mathrm{~mL}$ of methanol, where the mixture was shaken vigorously. Then, about $0.3 \mathrm{~mL}$ of sample was added with $2 \mathrm{~mL}$ of DPPH reagent and subsequently stirred well and kept in a dark environment for $30 \mathrm{~min}$. The absorbance of the mixture was measured at $515 \mathrm{~nm}$ by using a UV-visible spectrophotometer, Shimadzu UV-160A (Kyoto, Japan). The scavenging activity was calculated using the equation as following:

$\%$ Inhibition of DPPH $=\frac{(\text { Abs control }- \text { bs sample })}{\text { Abs control }} \times 100$
HIGH PERFORMANCE LIQUID CHROMATOGHAPHY (HPLC) ANALYSIS OF PHENOLICS

Tea catechin including $(+)$-catechin $(\mathrm{C}),(-)$-epicatechin (EC), (-)-epigallocatechin (EGC) and (+)-gallocatechin gallate, (GCG), gallic acid and caffeine were determined according to the HPLC method described in Liang et al. (2007). Each standard solution was prepared by dissolving $10 \mathrm{mg}$ of standard in ethanol and top up to $10 \mathrm{~mL}$ in a volumetric flask to make stock solution of $1000 \mathrm{mg} / \mathrm{L}$. Following that, serial dilutions were conducted to prepare standard solutions of 100, 200, 300, 400 and $500 \mathrm{mg} / \mathrm{L}$. Then each of the standard solution was filtered through a syringe filter of $0.45 \mu \mathrm{m}$ pore size into a $1.5 \mathrm{~mL}$ vial. The same procedures were carried out for the preparation of standard solutions of gallic acid, caffeic acid, $(+)$-catechin (C), (-)-epicatechin (EC), (-)-epigallocatechin (EGC), $(+)$-gallocatechin gallate, (GCG). In this study, gradient elution of mobile phase was applied. Thus, two types of mobile phase solution were prepared as mobile phase A and B. For mobile phase A, a mixture of acetronitrile, acetic acid and water was prepared in ratio 6:1:193. Meanwhile, for mobile phase B, a mixture of acetronitrile, acetic acid and water was prepared in ratio $60: 1: 139$. About $10 \mu \mathrm{L}$ of sample was injected into the HPLC with gradient elution of mobile phase B, increased from 30 to $85 \%$ by linear gradient within $35 \mathrm{~min}$ and further holding at $85 \%$ for 5 min at flow rate of $1 \mathrm{~mL} / \mathrm{min}$. The column of SB-C18 $5 \mu \mathrm{m}$, $4.6 \times 150 \mathrm{~mm}$ (Agilent, Technology, USA) was used. The column temperature was operated at room temperature and the chromatographic data was detecting at $280 \mathrm{~nm}$ wavelength. The concentration of each types of catechin in the tea extracts was determined by using the calibration curve of the standard solutions. The standard curve was constructed with the known concentration $(\mathrm{mg} / \mathrm{L})$ of the different types of catechins was plotted against the value of area (mV.s) obtained from the analysis.

\section{STARCH HYDROLYSIS BY ENZYME (A-AMYLASE)}

Starch hydrolysis by enzyme was determined according to method describe by Ahmad and Urooj (2010). The starch suspension (10\%) was prepared in $0.02 \mathrm{M}$ sodium phosphate buffer at $\mathrm{pH}$ 6.9. Tea extracts (1\%) from $50 \%$ $(\mathrm{v} / \mathrm{v})$ ethanol extraction was added into starch suspension. Then, $\alpha$-amylase from human saliva (type XI) $(0.01 \%)$ was added into starch slurry. The samples were incubated in the orbital incubator shaker (JEIO Tech, SI-600R, Seoul, Korea) at $37^{\circ} \mathrm{C}$ with the speed of $10 \mathrm{~g}$ in order to avoid sedimentation. Then, $1 \mathrm{~mL}$ of the starch suspension was withdrawn at various time intervals 30, 60, 90, 120, 180, $240 \mathrm{~min}$ for reducing sugar determination. A control test was carried out without sample of tea extracts. Duplicates of samples and control (without tea extracts) were prepared for every analysis.

\section{DEXTROSE EQUIVALENT (DE)}

Dinitrosalicylic acid method (Timell et al. 1956) was used to measure reducing sugar value to determine its dextrose equivalent (DE). Briefly, $1 \mathrm{~mL}$ of aliquot was withdrawn 
from each batch of starch suspension at various time intervals up to $3 \mathrm{~h}$ and was added into test tube. Then 3 $\mathrm{mL}$ of dinitrosalicylic acid solution (DNS) and $1 \mathrm{~mL}$ of distilled water were added into the test tubes. The solution was boiled at $100^{\circ} \mathrm{C}$ for $5 \mathrm{~min}$. Distilled water was added and cooled immediately by immerse the test tubes in water before it was shakes to mix it well by using vortex. The absorbance was measured at $504 \mathrm{~nm}$ using UV-visible spectrophotometer (Shimadzu UV-1601 PC, Japan). Glucose was used as a standard and each analysis was performed in duplicate. DE was calculated by:

$$
\mathrm{DE}=\frac{\mathrm{g} \text { reducing sugar expressed as glucose }}{\mathrm{g} \text { dry solid weight }} \times 100 \%
$$

\section{STATISTICAL ANALYSIS}

The data were analyzed using the two-way ANOVA tool under the Statistical Package for Social Science software (SPSS Inc.) version 18.0. The ANOVA and Duncan's Multiple Range test were completed to compile the mean values and standard deviation among the samples.

\section{DISCUSSION}

\section{TOTAL PHENOLICS CONTENT}

TPC in green, oolong and black tea leaf was measured in water, methanol and ethanol extracts. Phenolic compounds in plants behave as free radical scavengers and the antioxidant activity of most plants is due mainly to the presence of phenolic compounds (Skerget et al. 2005). The antioxidant mechanism of polyphenolic compounds is based on their hydrogen donating and metal ion chelating abilities (Lee et al. 2002). Table 1 shows the TPC of different types of tea leaf extracts measure using the Folin-Ciocalteu colorimetric method.

The solvent used for extraction affected the TPC. The ethanol extracts had the highest TPC, followed by the methanol and water extracts, for all three types of tea leaves analyzed. The ethanol extract of green tea leaves (231.24 mg GAE/g) had the highest TPC, followed the methanol (209.76 mg GAE/g) and water (136.51 mg GAE/g) extracts of green tea leaves. These results suggested that ethanol was a more efficient solvent than methanol and water. Phenolic compounds are often more soluble in organic solvents with less polarity and Turkmen at al. (2006) reported that the extractability of polyphenols is influenced by the polarity and viscosity of the solvents used. The methanol extract had higher TPC than the water extract. Demiray et al. (2009) also found that the aqueous methanol extracts higher TPC of several Turkish medicinal plants had higher TPC compared to water extracts. They also found that aqueous methanol was more efficient at extracting TPC of several medicinal plants compared to water.

Lin et al. (2003) reported that more ECGC was present in tea samples extracted with ethanol with ethanol (65$75 \%$ ) than with boiling water. Nwuha et al. (1999) found that caffeine and catechins were more soluble in ethanol than pure water. In addition, ethanol extractions often are used in human consumption models due their non-toxic properties (Alohman et al. 2009). The addition of water to the solvent enhances the extraction efficiency. In particular, mixtures of an organic solvent and water are more efficient at extracting phenolic compounds than the corresponding mono-component solvent system (Pinelo et al. 2005). In organic solutions, solvent concentration may affect the solubility of the phenolic compounds, especially glycosidic compounds. Solvent polarity also plays an important role in extraction efficiency; phenolic solubility increases with solvent polarity, whereas the least polar solvents are suitable for extraction of lipophilic phenols (Alothman et al. 2009).

Among the different types of tea leaves tested, green tea extract (136.51-231.23 mg GAE/g) contained the highest TPC, followed by oolong (66.89-189.09 $\mathrm{mg} \mathrm{GAE} / \mathrm{g}$ ) and black (52.42-124.34 mg GAE/g) tea extracts. These results indicated that green tea extracts are the richest source of phenolic compounds and black tea extracts are the poorest source. Thus, TPC in commercial teas was in the following order: green tea $>$ oolong tea $>$ black tea.

The green tea extract was expected to contain the highest TPC because fermentation is not used during processing of green tea leaves. In contrast, oolong and black teas are made by allowing, fresh tea leaves to ferment wither until the moisture content of the leaves is reduced. This process causes deterioration of leaf structural integrity and changes in polyphenol concentration. TPC of oolong tea was higher than that of black tea because the former undergoes only partial fermentation before drying, whereas black tea leaves are fully fermented (Huafu et al. 2000).

The results shown in Table 1 are in agreement with data reported by Lin et al. (2003) who found that green tea extract had the highest TPC, followed by oolong and black tea extracts. Chan et al. (2010) reported similar results. However, the TPC values measured in the current study for green and black teas were much higher than those reported by Khokhar and Magnusdottir (2002). The difference could be due to differences in types of tea leaves and growth conditions between the studies. The results from the current study illustrate that the solvent and type of tea leaves used affect the relative amount of phenolic compounds in tea leaves.

\section{TOTAL FLAVONOID CONTENT}

TFC in oolong, black and green tea leaves were measured in water, methanol and ethanol extracts. The TFC in tea extracts was measured using the aluminum chloride colorimetric assay, which is based on the color reaction of flavonoids with aluminum chloride $\left(\mathrm{AlCl}_{3}\right)$ in which acid labile complexes form with the orthodihydroxyl groups in the A- or B- rings of flavonoids (Zhishen et al. 1999). TFC was expressed as $\mathrm{mg}$ catechin equivalents (CEQ) per gram of the sample (Table 2).

TFC was highest in the ethanol extracts (28.87-61.67 $\mathrm{mg}$ CEQ/g) compared to the methanol (24.74-43.78 mg $\mathrm{CEQ} / \mathrm{g})$ and water $(9.88-28.45 \mathrm{mg} \mathrm{CEQ} / \mathrm{g})$ extracts. The TFC values of green and oolong tea ethanol and methanol 
extracts were significantly higher than those in the water extract. Thus, the recovery of flavonoids was solvent and polarity dependent. Alothman et al. (2009) reported that solvent polarity plays a key role in increasing phenol solubility.

Green tea extracts (27.57-61.67 mg CEQ/g) contained the highest TFC compared to oolong (9.88-41.22 $\mathrm{mg} \mathrm{CEQ} / \mathrm{g})$ and black (24.74-28.87 mg CEQ/g) tea extracts for all three different solvents (Table 2). Thus, green tea was the richest source of flavonoids and black tea contained the least amount of flavonoids. The TFC in commercial tea was in the order: Green tea $>$ oolong tea $>$ black tea.

Lin et al. (2003) also found that green tea contained the highest amount of catechins among the teas tested. Catechins are a group of polyphenolic flavan-3-ol monomers and their gallate derivatives and they are present in high amounts in tea. They include C, EC, EGC, ECG, and EGCG (Huafu et al. 2000). Green tea contain about 30-42\% catechins (dry mass basis) compared to black tea, which contains about $3-10 \%$ catechins, $2-6 \%$ theaflavins and $10-20 \%$ thearubigins (Balentine et al. 1997).

Degree of fermentation also plays an important role in catechin content, as ECGC and total catechin contents are inversely to the degree of fermentation (Lin et al. 2003). Oolong tea is prepared by partial fermentation before drying, thus its TFC is between those of green and black teas (Balentine et al. 1997).

\section{FERRIC REDUCING/ ANTIOXIDANT POWER (FRAP) ASSAY}

The FRAP assay was used to evaluate the antioxidant capacity of tea leaf extracts. The antioxidant capacity was determined by the ability of the polyphenol antioxidants from the extracts to reduce ferric ions to ferrous ions at low $\mathrm{pH}$ in FRAP reagent 2,4,6-Tris (1-pyridyl)-5-triazine prepared in sodium acetate buffer, $\mathrm{pH}$ 3.6. FRAP values were expressed as micromoles of ferrous equivalent $\mathrm{Fe}$ (II) per gram of sample (Table 3 ).

FRAP values differed among different types of tea leaves and different solvent extracts. The highest FRAP values were found in the ethanol extracts (124.34-231.23 $\mu \mathrm{mol} \mathrm{Fe}$ (II)/g), followed by the methanol (124.28$209.76 \mu \mathrm{mol} \mathrm{Fe}(\mathrm{II}) / \mathrm{g})$ and water (52.42-136.51 $\mu \mathrm{mol}$ $\mathrm{Fe}(\mathrm{II}) / \mathrm{g}$ ) extracts. The results of the FRAP assay showed trends similar to those of TPC, as the reducing potential of antioxidant components is very much associated with their TPC. Studies have suggested that changes in solvent polarity and viscosity may influence the antioxidant compound being extracted (Naczk \& Shahidi 2006).

For all three extraction solvents, green tea leaves had the highest FRAP values (136.51-231.23 $\mu \mathrm{mol} \mathrm{Fe} \mathrm{(II)/g),}$ followed by oolong $(66.89-189.09 \mu \mathrm{mol} \mathrm{Fe}$ (II)/g) and black (52.42-124.34 $\mu \mathrm{mol} \mathrm{Fe} \mathrm{(II)/g)} \mathrm{tea} \mathrm{leaves.} \mathrm{These}$ results showed that green tea was the richest source of antioxidants, whereas black tea extracts had the lowest antioxidant capacity among the three types of tea leaves. FRAP values followed the same trend as TPC: green tea $>$ oolong tea $>$ black tea leaves.

Uchenna et al. (2010) reported that green tea extracts possessed significantly higher antioxidant activity than oolong and black tea extracts due to the presence of additional antioxidant compounds, such as glycosylated flavonols, proanthocyanidins and phenolic acids, and their presence in green tea is evident as higher TPC values. Benzie and Szeto (1999) and Khokhar and Magnusdottir (2002) also described the correlation between antioxidant activities and TPC in different types of tea leaves. Horzic et al. (2009) reported that the antioxidant activity of tea is not determined by one or a few phytochemical compounds, but by a range of phenolic compounds including catechins.

The low FRAP values in black tea could be due to the presence of polymerized polyphenols in black tea leaves. Most of the polyphenols in black tea leaves are present as high molecular weight polymers such as theaflavins and thearubigins and some of the polyphenol reactive structures are still present (Vrhovsek et al. 2004). Higdon and Frei (2003), who reported that catechins are the most abundant phenolic compounds in green tea due to the degree of fermentation used to process the tea leaves. Therefore, FRAP values in different types of tea leaves varied because the chemical structures of phenolic compounds present differed among tea leaf type.

\section{FREE RADICAL SCAVENGING ABILITY (DPPH)}

The DDPH free radical scavenging assay is the most common method used to measure the antioxidant capacity of extracts (Alma et al. 2003). DPPH is commercially available stable organic nitrogen radical that has an unpaired valence electron at one atom of the nitrogen bridge (Eklund et al. 2005). DPPH is a dark colored crystalline powder composed of free radical molecules and it has two major applications: To monitor chemical reactions involving radicals and as a standard for the position and intensity of electron paramagnetic resonance signals. The radical nature of that reaction can be determined by measuring the rate reduction of the chemical reaction upon addition of DPPH. The abstraction of the hydrogen atom from the antioxidant compound changes the deep violet color of DPPH to a pale yellow color. Greater DPPH reduction is associated with greater antioxidant capacity in the extracts, which is reported as percentage of inhibition (\% inhibition). All procedures must be conducted in dark or dim light. The results are shown in Table 4.

The ethanol extracts had the highest antioxidant activity (26.62-61.39\% DPPH inhibition), followed by the methanol (30.35-44.71\% DPPH inhibition) and water (18.82-23.65\% DPPH inhibition) extracts. The ethanol extracts exhibited much stronger scavenging ability than the other two extracts and the water extracts showed the weakest scavenging ability. Siddhuraju and Becker (2003) reported that the water extracts exhibited poor scavenging of DPPH than ethanol extracts.

Among the three teas, oolong tea had the highest antioxidant activity (23.65-61.39\% DPPH inhibition) followed by green tea $(21.2-32.86 \% \mathrm{DPPH}$ inhibition) and black tea (18.82-37.17\% DPPH inhibition), for all three solvents extracts. Yen and Chen (1995) also found that oolong tea leaf extracts exhibited marked antioxidant activity and reducing power. 
DPPH scavenging activity of phenolic compounds in tea leaf extracts is positively correlated with the number of hydroxyl groups (Sroka \& Cisowki 2003). Polarity of the reaction medium, solubility of the compound, chemical structure of the radical scavenger and $\mathrm{pH}$ of the reaction mixture also influence DPPH radical scavenging activity (Saito et al. 2004). The observed differences in DPPH activity in different types of extracts and teas could be due to one or more of these factors. Synergy or antagonism among the different classes of polyphenols and the radical molecules contained in tea extracts also may affect antioxidant activity.

\section{HIGH PERFORMANCE LIQUID CHROMOTAGRAPHY} ANALYSIS

A simple and fast HPLC method using a photodiode array detector was developed for simultaneous measurement of four major catechins: $(+)$-catechin $(\mathrm{C}),(-)$-epicatechin (EC), (-)-epigallocatechin (EGC), (+)-gallocatechin gallate, (GCG). In this study, gradient elution of mobile phase was applied. Thus, two types of mobile phase ca gallic acid and caffeine in ethanol extracts green, oolong and black tea, as ethanol exhibited the highest extraction efficiency (Table 5).

Gallic acid and caffeine were present in all sample extracts. Gallic acid content ranged from 4.48 to 14.64 $\mathrm{mg} / \mathrm{g}$ dry weight of extract and was highest in green tea, followed by oolong and black tea. Caffeine content ranged from 41.89 to $139.62 \mathrm{mg} / \mathrm{g}$ dry weight of extract and also was highest in green tea and lowest in black tea. Gallic acid, caffeine and all four catechins were major components in green and oolong teas, but only GCG was present in black tea. All four catechins were present at higher levels in green tea than in oolong tea.

Gallic acid is the main phenolic acid present in tea extracts and all teas contain large amounts of caffeine. The contents of tea catechins, gallic acid and caffeine are related to the quality of tea leaves and the degree of fermentation that occurs during tea manufacturing. In general, green tea contains higher levels of catechin than oolong tea. The catechin content of black tea is very low due to the extensive fermentation process (Balentine 1997). During fermentation, tea catechins are oxidized or condensed to other large polyphenolic molecules such as theaflavins and thearubigins (Balentine 1997). Lin et al. (2003) reported that the level of EGCG in black tea was very low compared to green and oolong teas, whereas the level in green tea was highest.

\section{STARCH HYDROLYSIS}

Activities of digestive enzymes such as amylase, glucosidase, pepsin, trypsin and lipases are known to be inhibited by polyphenols (Rohn et al. 2002). Polyphenols may act as inhibitors of carbohydrate-hydrolyzing enzymes such as $\alpha$-amylase and $\alpha$-glucosidase and reduce the rate of glucose absorption, consequently leading to reduction of post-prandial hyperglycemia (Bailey 2001). Phenolic compounds delay carbohydrate digestion and prolong overall carbohydrate digestion time (Rhabasa-Lhoret \& Chiasson 2004).

Figure 1 shows the inhibitory potencies of green, oolong and black tea extracts on $\alpha$-amylase activity. A control test was carried out by replaced the sample of tea extracts with distilled water. After $240 \mathrm{~min}$ of starch hydrolysis, the control contained the highest dextrose equivalent (DE) $(7.56 \%)$, followed by green tea $(6.76 \%)$, oolong tea $(6.32 \%)$ and black tea $(6.09 \%)$. Thus, starch hydrolysis was highest in the control due to the absence of phenolic compounds that can inhibit of $\alpha$-amylase activity. The DE value was lowest for the black tea extracts, which indicates the phenolic compounds in black tea had a strong $\alpha$-amylase inhibitory effect. The extent of starch hydrolysis followed the order: green $>$ oolong $>$ black tea. DE and starch hydrolysis were inversely correlated with inhibitory effect. Therefore, the low degree of starch hydrolysis for black tea was indicative of high inhibition of $\alpha$-amylase activity and the inhibition of $\alpha$-amylase activity in vitro followed the order: Black $>$ oolong $>$ green tea.

Hara and Honda (1990) reported that the aflavins have a much stronger inhibitory effect on $\alpha$-amylase than catechins. In the current study, free catechins (EC and EGC) and their isomers as well as gallic acid did not have significant effects on the activity of $\alpha$-amylase. This result suggests that black tea had the highest $\alpha$-amylase inhibitory properties and was more active as an inhibitor against $\alpha$-amylase due to its higher molecular weight polyphenols, the aflavins and the arubigins, which are more abundant in black tea than in green and oolong tea. The heterogeneity of phenolic compounds with different structural features may explain the starch hydrolysis results. In terms of chemical composition, green tea contains simple catechins, which are polyphenols with low molecular weight ((MW) $<450$ Da). In contrast, black tea is oxidized and condensed and contains larger and more complex molecules, including the aflavins (MW 500-1000 Da) and the arubigins (MW >1 $\mathrm{kDa}$ ) and these complex molecules are microbiologically active (Huafu et al. 2000). Simple phenols have little effect on enzymes and it appears that a minimum MW of $>500$ is necessary for inhibitory activity. The content of the aflavins in black tea is $2-6 \%(\mathrm{w} / \mathrm{w})$ and that of the arubigins is $10-20 \%(\mathrm{w} / \mathrm{w})$ of the dry matter of black teas (Balentine et al. 1997). Oolong tea is semi-fermented and contains a mixture of monomeric and oligomeric catechins. Thus, the inhibitory effect of tea extracts on $\alpha$-amylase can be attributed to the amount of high MW polyphenols present in the extracts.

Many studies have suggested that individual polyphenols or classes of polyphenols directly influence the activities of key enzymes independent of their antioxidant capacities (Gordon et al. 2005). The results of this study showed that three types of tea, which differ in chemical composition and have different affinities for enzymes have different patterns of saliva $\alpha$-amylase inhibition. Jianbo et al. (2011) reported that the binding process of polyphenols with $\alpha$-amylase was strongly influenced by structural differences in the phenolic compound, 
whereas the binding interaction between polyphenols and $\alpha$-amylase was mainly due to hydrophobic forces and hydrogen bonding. Rohn et al. (2002) found that a decrease in enzyme activity depends on the number and position of hydroxyl groups of the phenolic compounds. Phenolic compounds are known to block nucleophilic sites of degradative enzymes by binding to amino acid side chains, which could inhibit $\alpha$-amylase activity. Polyphenols also can bind to starch and affect starch gelatinization or its accessibility to digestive enzymes or calcium, which is needed to stabilize amylase activity (Lilian 1994). In addition, there is a negative relationship between presence of phenolic compounds and in vitro rate of starch digestion. Our results are in agreement with those of several other in vitro studies that showed the inhibitory properties of polyphenol in tea extracts against $\alpha$-amylase activity (Hara \& Honda 1990; Jianbo et al. 2011; McDougall et al. 2005).

Zhang et al. (1997) reported that catechin was effective only at concentrations $>2 \mathrm{mg} / \mathrm{mL}$, but it still was not considered to be a potent inhibitor due to its lower inhibition percentage. The 3, 4, 5 -trihydroxybenzoyl moiety at $3-\mathrm{OH}$ in catechin is essential for inhibition, and its activity is affected by the stereostructure of the B ring. Galloylated catechins have higher binding affinities with $\alpha$-amylase than nongalloylated catechins and the pyrogallol-type catechins have higher affinities than the catechol-type catechins. For black tea, which strongly inhibits $\alpha$-amylase activity, an increase in the number of galloyl moieties enhances their inhibitory potency (e.g. theaflavin digallate (TF3) $>$ theaflavin monogallate (TF2) $>$ theaflavin (TF1)) (Hara \& Honda 1990).

\section{CONCLUSION}

In this study, inhibition of $\alpha$-amylase from human saliva by polyphenolic components of different types of tea and different aqueous solvent extracts was detected in vitro. The results strongly suggested that ethanol is the most efficient solvent for extracting phenolic compounds from (black, green and oolong) tea leaves. The ethanol extracts of all three types of tea had higher TPC, TFC and antioxidant activity compared to the methanol and water extracts. In addition, green tea had higher TPC, TFC and FRAP antioxidant activity compared to black and oolong tea. Thus, green tea contained the highest levels of phenolic compounds and the greatest antioxidant activity among the three types of tea leaves. HPLC results also indicated that green tea contained higher amount of catechins than oolong and black tea. All three tea leaf extracts showed potential to act as enzyme inhibitors. However, black tea extracts had the greatest inhibitory effect on $\alpha$-amylase, flowed by oolong and green tea extracts. The low degree of starch hydrolysis for black tea was evident from the strong inhibition of $\alpha$-amylase activity. In summary, the different types of tea affected the activity of $\alpha$-amylase to different degrees due to their different compositions and structures of phenolic compounds.

\section{ACKNOWLEDGEMENTS}

This work was supported by Fundamental Research Grant (203/PTEKIND/6711371) and Universiti Sains Malaysia (USM), Penang, Malaysia.

\section{REFERENCES}

Ahmed, F. \& Urooj, A. 2010. In vitro studies on the hypoglycemic potential of Ficus racemosa stem bark. Journal of the Science of Food and Agriculture 90(3): 397-401.

Alma, M.H., Mavi, A., Yildirim, A., Digrak, M. \& Hirata, T. 2003. Screening chemical composition and in vitro antioxidant and antimicrobial activities of the essential oils from Origanum syriacum 1. growing in turkey. Biological and Pharmaceutical Bulletin 26: 1725-1729.

Alothman, M., Bhat, R. \& Karim, A.A. 2009. Antioxidant capacity and phenolic content of selected tropical fruits from Malaysia, extracted with different solvent. Food Chemistry 115: 785-788.

Apostolidis, E. \& Lee, C.M. 2010. In vitro potential of Ascophyllum nodosum phenolic antioxidant-mediated alpha-glucosidase and alpha-amylase. J. Food Sci. 75: 97-102.

Bailey, C.J. 2001. New approaches to the pharmacotherapy of diabetes. 3rd ed. In Text Book of Diabetes, edited by Pickup, J.C. \& William, G. UK: Blackwell Science Ltd. 2: 73.1-73.2

Balentine, D.A. 1997. Manufacturing and chemistry of tea. In Phenolic Compounds in Food and their Effects on Health, Antioxidants and Cancer Prevention, edited by Ho, C.T., Lee, C.Y. \& Huang, M.T. Washington: American Chemical Society.

Benzie, I.F.F. \& Szeto, Y.T. 1999. Total antioxidant capacity of teas by the ferric reducing/antioxidant power assay. Journal of Agricultural and Food Chemistry 47: 633-636.

Bhoo, P.N., Peeters, P., van Gils, C., Beulens, J.W.J., van der Graaf, Y. \& Bueno-de-Mesquita, B. 2010. Coffee and tea intake and risk of breast cancer. Breast Cancer Research and Treatment 121: 461-467.

Chan, E.W.C., Lim, Y.Y., Chong, K.L., Tan, J.B.L. \& Wong, S.K. 2010. Antioxidant properties of tropical and temperate herbal teas. Journal of Food Composition and Analysis 23: 185-189.

Chen, N., Bezzina, R., Hinch, E., Lewandowski, P.A., CameronSmith, D., Mathai, M.L., Jois, M., Sinclair, A.J., Begg, D.P., Wark, J.D., Weisinger, H.S. \& Weisinger, R.S. 2009. Green tea, black tea, and epigallocatechin modify body composition, improve glucose tolerance, and differentially alter metabolic gene expression in rats fed a high-fat diet Nutr. Res. 29(11): 784-793.

Demiray, S., Pintado, M.E. \& Castro, P.M.L. 2009. Evaluation of phenolic profiles and antioxidant activities of Turkish medical plants: Tilia argentea, Crataegi folium leaves and Polygonum bistorta roots. World Academy of Science, Engineering and Technology 3: 06-24.

Eklund, P.C., Langvik, O.K., Warna, J.P., Salmi, T.O., Willfor, S.M. \& Sjoholm, R.E. 2005. Chemical studies on antioxidant mechanisms and free rradical scavenging properties of lignans. Organic and Bimolecular Chemistry 21: 3336-3347.

Gordon, J., Mcdougall, Faina, S., Patricia, D., Pauline, S., Alison, B. \& Derek, S. 2005. Different polyphenolic components of soft fruits inhibit $\alpha$-amylase and $\alpha$-glucosidase. J. Agric. Food Chem. 53: 2760-2766. 
Hara, Y. \& Honda, M. 1990. The inhibition of $\alpha$-amylase in tea polyphenols. Agric. Biol. Chem. 54: 1939-1945.

Higdon, J.V. \& Frei, B. 2003. Tea catechins and polyphenols: Health effects, metabolism and antioxidant functions. Crit. Rev. Food Sci. Nutr. 43: 89-143.

Horzic, D., Komes, D., Belscak, A., Ganic, K.K., Ivekovic, D. \& Karlovic, D. 2009. The composition of polyphenols and methylxanthines in teas and herbal infusions. Food Chem. 115: 441-448.

Huafu, W., Gordon, J.P. \& Keith, H. 2000. Tea flavonoids: Their functions, utilisation and analysis. Trends in Food Science \& Technology 11: 152-160.

Jeszka-Skowron, M., Zgoła-Grzes'kowiak, A. \& Grzes'kowiak, T. 2015. Analytical methods applied for the characterization and the determination of bioactive compounds in coffee. Eur. Food Res. Technol. 240: 19-31.

Jianbo, X., Guoyin, K., Xiaoling N., Fan, Y. \& Xiaoqing, C. 2011. Interaction of natural polyphenols with $\alpha$-amylase in vitro: Molecular property-affinity relationship aspect. Mol. BioSyst. 7: 1883-1890.

Khokhar, S. \& Magnusdottir, S.G.M. 2002. Total phenol, catechin, and caffeine contents of teas commonly consumed in the United Kingdom. J. Agric. Food Chem. 50: 565-570.

Kim, Y., Goodner, K.L., Park, J.D., Choi, J. \& Talcott, S.T. 2011. Changes in antioxidant phytocemicals and volatile composition of Camellia sinensis by oxidation during tea fermentation. Food Chemistry 129: 1331-1342.

Kwon, Y.I., Apostolidis, E. \& Shetty, K. 2008. Inhibitory potential of wine and tea against alpha-amylase and alpha-glucosidase for management of hyperglycemia linked to type 2 diabetes. J. Food Biochem. 32: 15-31.

Lee, M.J., Maliakal, P., Chen, L., Meng, X., Bondoc, F.Y., Prabhu, S., Lambert, G., Mohr, S. \& Yang, C.S. 2002. Pharmacokinetics of tea catechins after ingestion of green tea and (-)-epigallocatechin-3-gallate by humans: Formation of different metabolites and individual variability. Cancer Epidemiol., Biomarkers Prev. 10: 1025-1032.

Liang, H., Liang, Y., Dong, J., Lu, J., Xu, H. \& Wang, H. 2007. Decaffeination of fresh green tea leaf (Camellia sinensis) by hot water treatment. Food Chemistry 101: 1451-1456.

Lilian, U.T. 1994. Potential health benefits and problems associated with antinutrients in foods. Food Research International 93: 963-969.

Lin, Y., Tsai, Y., Tsay, J. \& Lin, J. 2003. Factors affecting the levels of tea polyphenols and caffeine in tea leaves. J. Agric. Food Chem. 51: 1864-1873.

Liu, X., Zho, M., Wang, J., Yang, B. \& Jiang, Y. 2008. Antioxidant activity of methanolic extract of emblica fruit (Phyllanthus emblica L.) from six regions in China. Journal of Food Composition and Analysis 21(3): 219-228.

Mcdougall, G.J. \& Stewart, D. 2005. The inhibitory effects of berry polyphenols on digestive enzymes. Biofactors 23: 189-195.

Naczk, M. \& Shahidi, F. 2006. Phenolics in cereals, fruits and vegetables: Occurance, extraction and analysis. Journal of Pharmaceutical and Biomedical Analysis 41: 1523-1542.

Naldi, M., Fiori, J., Gotti, R., Pe' riat, A., Veuthey, J.L., Guillarme, D. \& Andrisano, V. 2014. UHPLC determination of catechins for the quality control of green tea. Journal of Pharmaceutical and Biomedical Analysis 88: 307-314.

Nwuha, V., Nakajima, M., Tong, J. \& Ichikawa, S. 1999. Solubility study of green tea extracts in pure solvents and edible oils. J. Food Eng. 40: 161-165.
Pan, X., Niu, G. \& Liu, H. 2003. Microwave-assisted extraction of tea polyphenols and tea caffeine from green tea leaves. Chemical Engineering and Processing 42(2): 129-133.

Pinelo, M., DelFabbro, P., Marzocco, L., Nunez, M.J. \& Vicoli, M.C. 2005. Optimization of continuous phenol extraction from vitis vinifera byproducts. Food Chem. 92: 109-117.

Rhabasa-Lhoret, R. \& Chiasson, J.L. 2004. $\alpha$-Glucosidase inhibitors, In International Textbook of Diabetes mellitus, vol. 1, 3rd ed, edited by Defronzo, R.A., Ferrannini, E., Keen, H. \& Zimmet, P. U.K. John Wiley \& Sons Ltd. pp. 901-914.

Rohn, S., Rawel, H.M. \& Kroll, J. 2002. Inhibitory effects of plant phenols on the activity of selected enzymes. Journal of Agricultural Food Chemistry 50: 3566-3571.

Rusak, G., Komes, D., Likic', S., Horz 'ic', D. \& Kovac`, M. 2008. Phenolic content and antioxidative capacity of green and white tea extracts depending on extraction conditions and the solvent used. Food Chemistry 110: 852-858.

Saito, S., Okamoto, Y. \& Kawabata, J. 2004. Effect of alcoholic solvents on antiradical abilities of protocatechuic acid and its alkyl esters. Bioscience Biotechnology and Biochemistry 68: 1221-1227.

Sanchez-Moreno, C., Larrauri, J.A. \& Saura-Calixto, F. 1998. A procedure to measure the antiradical efficiency of polyphenols. Journal of the Science of Food and Agriculture 76: 270-276.

Siddhuraju, P. \& Becker, K. 2003. Antioxidant properties of various extracts of total phenolic constituents from three different agroclimatic origins of drumstick tree (Moringa oleifera lam.) leaves. J. Agric. Food Chem. 51: 2144-2155.

Skerget, M., Kotnik, P., Hadolin, M., Hras, A.R., Simonic, M. \& Knez, Z. 2005. Phenols, proanthocyanidins, flavones and flavonols in some plant materials and their antioxidant activities. Journal of Food Chemistry 89: 191-198.

Sroka, Z. \& Cisowski, W. 2003. Hydrogen peroxide scavenging, antioxidant and antiradical activity of some phenolic acids. Food and Chemical Toxicology 41: 753-758.

Szymczycha-Madeja, A., Welna, M. \& Poh1, P. 2015. Determination of essential and non-essential elements in green and black teas by FAAS and ICP OES simplifiedmultivariate classification of different tea products. Microchemical Journal 121: 122-129.

Timell, T.E., Glaudemans, C.P.J. \& Currie, A.L. 1956. Spectrophotometric methods for determination of sugars. Anal. Chem. 28: 1916-1920.

Tresserra-Rimbau, A., Rimm, E.B., Medina-Remon, A., Martinez-Gonzalez, M.A., de la Torre, R., Corella, D., Salas-Salvado, J., Gomez-Gracia, E., Lapetra, J., Aros, F., Fiol, M., Ros, E., Serra-Majem, L., Pinto, X., Saez, G.T., Basora, J., Sorli, J.V., Martinez, J. A., Vinyoles, E., Ruiz Gutierrez, V., Estruch, R. \& Lamuela-Raventos, R.M. 2014. Inverse association between habitual polyphenolintake and incidence of cardiovascular events in the PREDIMED study. Nutr. Metab. Cardiovasc. Dis. 24(6): 639-647.

Turkmen, N., Sari, F. \& Velioglu, Y.S. 2006. Effects of extraction solvents on concentration and antioxidant activity of black and black mate tea polyphenols determined by ferrous tartrate and Folin-Ciocaltue methods. Food Chemistry 99: 835-841.

Uchenna, J.U., Selena, A., Adam, K., James, T.L. \& Edward, J.K. 2010. White and green teas (Camellia sinensis var. sinensis): Variation in phenolic, methylxanthine, and antioxidant profiles. Journal of Food Science 75: 66-78. 
Vrhovsek, U., Rigo, A., Tonon, D. \& Mattivi, F. 2004. Quantitation of polyphenols in different apple varieties. Journal of Agricultural and Food Chemistry 52: 6532-6538.

Yen, G.C. \& Chen, H.Y. 1995. Antioxidant activity of various tea extracts in relation to their antimutagenicity. J. Agric. Food Chem. 43: 27-32.

Zhang, J. \& Kashket, S. 1997. Inhibition of salivary amylase by black and green teas and their effects on the intra-oral hydrolysis of starch. Caries Res. 32: 233-238.

Zhishen, J., Mengcheng, T. \& Jianming, T. 1999. The determination of flavonoid content in mulberry and their scavenging effects on superoxide radicals. Food Chem. 64: $555-559$.
Zimmermann, B.F. \& Gleichenhagen, M. 2011. The effect of ascorbic acid, citric acid and low $\mathrm{pH}$ on the extraction of green tea: How to get most out of it. Food Chemistry 124: 1543-1548.

Food Technology Division

School of Industrial Technology

Universiti Sains Malaysia

Minden 11800, Pulau Pinang

Malaysia

*Corresponding author; email: sapina@usm.my

Received: 13 June 2017

Accepted: 26 October 2017 
